Family Profile No. 14, 2019

\title{
Marriage by the Numbers
}

\author{
Author: Wendy D. Manning \& Krista K. Payne
}

Summer is the season for weddings in the United States. It is a time for celebrating and bringing together family and friends. Here are some marriage facts to help newlyweds understand more about their new marital status.

\section{Number of Marriages}

- $\quad$ In 2017, there were $2,236,496$ marriages in the U.S. ${ }^{1}$

\section{Number of Married Couples}

- $\quad$ There were over 63.7 million married couples in the U.S. in $2018 .^{2}$

\section{Share of the Adult Population Who Are Married}

- About one-half of the U.S. adult population is currently married. ${ }^{2}$

\section{Median Age at $1^{\text {st }}$ Marriage}

- The median at first marriage is approaching 30 years for men and 28 years for women. ${ }^{3}$

\section{Share of Marriages That Are Remarriages}

- Among women who married in $2017,27 \%$ were entering a remarriage. ${ }^{4}$

\section{Recent Family Profiles on Marriage}

Want to know more about marriage in the U.S.? Check out the most recent published Family Profiles on the topic:

\section{FP-19-12 High School Seniors' Ideal Time for Marriage, 2017}

FP-19-11 High School Seniors' Expectations to Marry, 2017

FP-19-10 High School Seniors' Attitudes Toward Cohabitation as a Testing Ground for Marriage, 2017

FP-19-08 First Marriage vs. Remarriage in the U.S., 2017

FP-19-07 Median Age at First Marriage: Geographic Variation, 2017

FP-19-06 Median Age at First Marriage, 2017

FP-19-05 Age Variation in the First Marriage Rate, 1990 \& 2017

FP-19-03 Marriage-to-Divorce Ratio in the U.S.: Geographic Variation, 2017

FP-18-20 Marriage Rate in the U.S.: Geographic Variation, 2017

\section{Suggested Citation:}

Manning, W. D. \& Payne, K. K. (2019). Marriage by the numbers. Family Profiles, FP-19-14. Bowling Green, OH: National Center for Family \& Marriage Research. https://doi.org/10.25035/ncfmr/fp-19-14.

1. CDC/NCHS National Vital Statistics System

2. IPUMS-CPS, University of Minnesota, www.ipums.org

3. U.S. Census Bureau, Current Population Survey, March and Annual Social and Economic Supplements, link 4. Schweizer, 2019 FP-19-08

\section{BGSU. $\mid \begin{aligned} & \text { National Center for } \\ & \text { Family \& Marriage Research }\end{aligned}$}

